\title{
Canoeing as a Counter-Hegemonic Practice: I Can, Can You?
}

\author{
Noor F.K. Iqbal
}

\begin{abstract}
This essay analyzes a silent short film portraying an urban canoeist. The film suggests that it is possible to make conscious choices about one's means of conveyance through the city. Using a critical theoretical framework to unpack the implications of the film, this paper argues for the need to imagine unconventional modes of transportation and examine the power structures of automotive hegemony.
\end{abstract}

In the silent short film "I Can, Can You?" presented at the 2009 Toronto Urban Film Festival, director/actor Neil Cumming of Dundas, Ontario portrays his morning routine. ${ }^{1}$ After a cup of coffee, he grabs his backpack and heads out the door to the apartment complex car park in the basement. The scene cuts to him carrying his canoe out the garage door, and portaging through the city. The canoe is a source of fascination to many passers-by, including a young child who mimics him as he walks along the sidewalk. Crossing the streets, he comes to a public wharf where he launches his canoe and paddles past factories and under bridges. The current strengthens, and he takes time to relax, reading his newspaper in the sunshine. Further on, he observes a heron taking flight and a turtle swimming through the sparkling water. He pulls into an eddy along a grassy bank and portages the canoe back up into the city streets. Coming to his destination, he locks up the canoe at a bike stand on the sidewalk and enters a shop.

It is easy to link using a canoe as a mode of transportation in the modern world with a desire to return to "unspoilt nature" and a simpler past, which could be grouped with other "sentimental objections" to the 'march of progress', readily dismissed as "reactionary" Luddism. ${ }^{2}$ A literal reading of "I Can, Can You?" sees 'taking a canoe to work' as a nostalgic re-enactment of the transportation practices of the previous century, allowing the paddler to connect either with nature as a "spiritual refreshment" or with the Canadian heritage of canoeing. ${ }^{3}$ On the other hand, the short film could also be seen as an exploration of the director's idiosyncratic desire to paddle through the city.

However, Cumming's film does not easily lend itself to such readings. Rather, the film invites reflection about how we per/re-ceive the world as we move through it, and how the mode of transportation we choose shapes the range of possible experiences. As Michel de Certeau emphasizes, "spatial practices in fact secretly structure the determining conditions of social life." Following Foucault's ideas of how the structures of power produce disciplinary spaces, de Certeau suggests that the practices carried out within such spaces contribute in their production. He explores the

1 Neil, Cumming, "I Can, Can You?”, short film, Toronto Urban Film Festival, 2009. http://www.torontourbanfilmfestival.com/node/178, accessed April 6, 2010.

2 Raymond Williams, "Ideas of Nature," in The Cultural Studies Reader, Third Edition, ed. Simon During (London: Routledge, 2007), 291.

${ }^{3}$ Ibid., 294.

4 Michel de Certeau, "Walking in the City," in The Cultural Studies Reader, Third Edition, ed. Simon During (London: Routledge, 2007), 161. 
practice of walking as opposed with cartographic "surveys" and representations "of routes." The metonymy by which "the traces left behind," such as well-worn pathways, stand in for the practice of walking or "the act of passing by" constitutes a way "to transform the action into legibility, but in doing so [...] causes a way of being in the world to be forgotten." of walking" in which the walker spells out the meaning given to space in a way that goes beyond living within the punctuation of street names and corners. This "poetic geography on top of the geography of the literal, forbidden or permitted meaning" is built of the network of lives and lived practices in the city, countering the suspension of the "symbolic order" imposed upon the city by the "logic of the techno-structure."

Similarly, Cumming's film portrays a way of being and thinking within our spatial environments that emphasizes the action over the map, the conscious perception over the normal(ized), passive way of moving through space. The film "I Can, Can You?" is not challenging the viewer to take a canoe to work, not everyone has a river conveniently running between home and work; it is not a mode of transportation available to all who see the film. Rather, it focuses the attention of the viewer upon modes of transportation and how they structure our perception of the world. For example, the paddler in the film interacts with the rhythms of the river physically providing his own power of locomotion. He takes time to 'smell the flowers,' noticing the flora and fauna around him. Furthermore, others see him as a curiosity, enabling enhanced interpersonal interactions as he becomes a role model, not only to the child who pretends to be also carrying a canoe, but every viewer who takes up the challenge in the title of the film. All of these interactions, perceptions, and receptions take place in opposition to the ways of being and/in motion cultivated by more common modes of transit such as cars, buses, subways, and, arguably, even bicycles. The striking nature of 'canoe transit' is effective in this film because of its difference: it startles and delights the viewer into recognizing another way of living in space and becoming conscious of the environment.

Another example of a widening of the cultural practice of transit is described in a news article from the Canadian Mennonite University in Winnipeg, Manitoba. The annual "Resource Conservation Manitoba's Campus Commuter Challenge" is generally understood as an invitation to students to travel by carpool, bus, bike, or on foot to class. Six students decided to take this a step further and travelled by canoe down the Assiniboine River to campus. Their project was to "find as many ways as possible to commute to school," while emphasizing the environmental impact of transit, the feasibility of "alternative forms of transportation," and the historical significance of non-mechanized vehicles in Canada's past. ${ }^{8}$ Other modes of transit the group planned to use included cross-country skiing and snowshoeing, practices that similarly enable a difference of perception of the world from the contemporary norm.

However, "I Can, Can You?", should not be read as a pure allegory. What is significant about the image of the canoe and the practice of paddling themselves? Refusing to reduce a poem to its content allows us to recognize what is important about its form. As noted above, the canoe is widely known as a common-piece of Canadian leisure that is here used in a different way. Instead of fitting into the structures of the middle-class canoe trip/holiday, Cumming's use of the canoe creates a parallel with the function of a car. As he carries the canoe out of the underground parkade, Cumming has already replaced the commuter car with a counter-hegemonic vehicle. As Dick Hebdige writes, quoting

${ }^{5}$ Ibid.

${ }^{6}$ Ibid.

${ }^{7}$ Ibid., 162.

8 "CMU Students Canoe to School," Canadian Mennonite University News (2008). http://www.cmu.ca/news/200809/Canoe.html, accessed April 6, 2010. 
Stuart Hall, Roland Barthes, and Antonio Gramsci, hegemony is the exertion of "total social authority [...] not simply by coercion," but rather by manufacturing consent to make dominant power (and practices) "appear both legitimate and natural." If we accept that the hegemonic mode of transportation today is the car, Cumming's paddle through the city becomes a statement aimed at altering the perception of the car as the 'natural' form of transit.

This reflection calls for a further question: is it possible to drive a car like one would paddle a canoe? While a film made about a man's continuous interaction with his environment while driving a car would clearly not have been as effective, is the car an object of everyday life that could be "symbolically 'repossessed"? ${ }^{10}$ At first glance, the answer might seem to lie in the difference of fuel sources. Bicycling and walking are often seen as 'green alternatives' to driving, as the abovementioned Campus Commuter Challenge indicates. While canoeing is un-mechanized, it cannot fully be categorized with other modes of self-powered transportation, as it can rely heavily on the current of the river. This is key to understanding the significance of paddling as a way of perceiving the world, for it demands an active interaction with and dependence upon the world, particularly the river; thus requiring a greater awareness of one's surroundings.

Barthes' definition of work vs. text might be stretched to gloss this cultural car/canoe binary. A work, says Barthes, is "an object of consumption," a classical, petrified, static, and dominant object. ${ }^{11}$ The car, in its early stages, was an exciting new way of traveling quickly through the world, but has since these early stages have become the dominant and unreflexive mode of movement. While it is perhaps not impossible to subvert the hegemony/work of the car into a more conscious practice/text-one could drive slowly with the windows open, interacting with pedestrians on the sidewalks and the plants and urban wildlife - the cultural structural framework around the practice of driving makes it very difficult. The rules of the road, the enclosed space and shape of the car, the normal speed of travel, and even the comfortable bucket seats are all structured to prevent an active, personal interaction with the land, roads, and streets upon which we drive.

A text, on the other hand, must be experienced "only in an activity,"12 "confront[s] the work" to produce "a new object, obtained by a shift or a reversal of the previous categories." "The text also "fulfills the very plurality of meaning: an irreducible (and not just acceptable) plurality." 14 The practice of paddling structurally lends itself to varied and multifarious modes. The paddler has the opportunity to bask in the sun, read the newspaper, observe other lives on the river, become empowered through his own physical work as a source of movement, respect the power of the water, build her canoeing skills, etc., all the while moving towards the destination.

The title of Neil Cumming's film, "I Can, Can You?" issues a challenge to the viewer. It suggests that it is possible to make conscious choices about one's means of conveyance through the city. Although the title may seem to be advocating water travel as a conceivable option, the canoe serves more explicitly as a way to startle the viewer, as it does the passers-by on the sidewalks, into imagining other unconventional modes of transportation. The sixty-second short film emphasizes

\footnotetext{
9 Dick Hebdige, "Subculture and Style," in The Cultural Studies Reader, Third Edition, ed. Simon During (London: Routledge, 2007), 438.

${ }^{10}$ Ibid., 439.

11 Roland Barthes, "From Work to Text," in The Cultural Studies Reader, Third Edition, ed. Simon During (London: Routledge, 2007), 85.

12 Ibid., 83

${ }^{13}$ Ibid., 82. The car, as we know, can usually "shift" into five gears, and "reverses" only in one. It would appear that the shifts and reversals called for by Barthes exceed the transmission capacity of most automobiles.

${ }^{14}$ Ibid., 84.
} 
the benefits of alternative vehicles. Canoe commuting shifts the balance of power by removing the paddler from mass modes of transit. Instead of just another body on the subway or another car on the highway, the paddler is now an active participant in his process of movement from one space to another. As a counter-hegemonic practice, canoeing allows the paddler to receive and experience the texture of the world. De Certeau's urban walker has found a canoe. 


\section{Bibliography}

Barthes, Roland. "From Work to Text." In The Cultural Studies Reader, Third Edition, edited by Simon During, 81-87. London: Routledge, 2007.

Cumming, Neil. "I Can, Can You?” Short film, Toronto Urban Film Festival. 2009. http://www.torontourbanfilmfestival.com/node/178. Accessed April 6, 2010.

de Certeau, Michel. "Walking in the City." In The Cultural Studies Reader, Third Edition, edited by Simon During, 156-163. London: Routledge, 2007.

Hebdige, Dick. "Subculture and Style." In The Cultural Studies Reader, Third Edition, edited by Simon During, 429-440. London: Routledge, 2007.

Williams, Raymond. “Ideas of Nature.” In The Cultural Studies Reader, Third Edition, edited by Simon During, 283-297. London: Routledge, 2007. 